\title{
¿Museo o Luna Park?
}

Alfonso Castrillon Vizcarra

Universidad Ricardo Palma

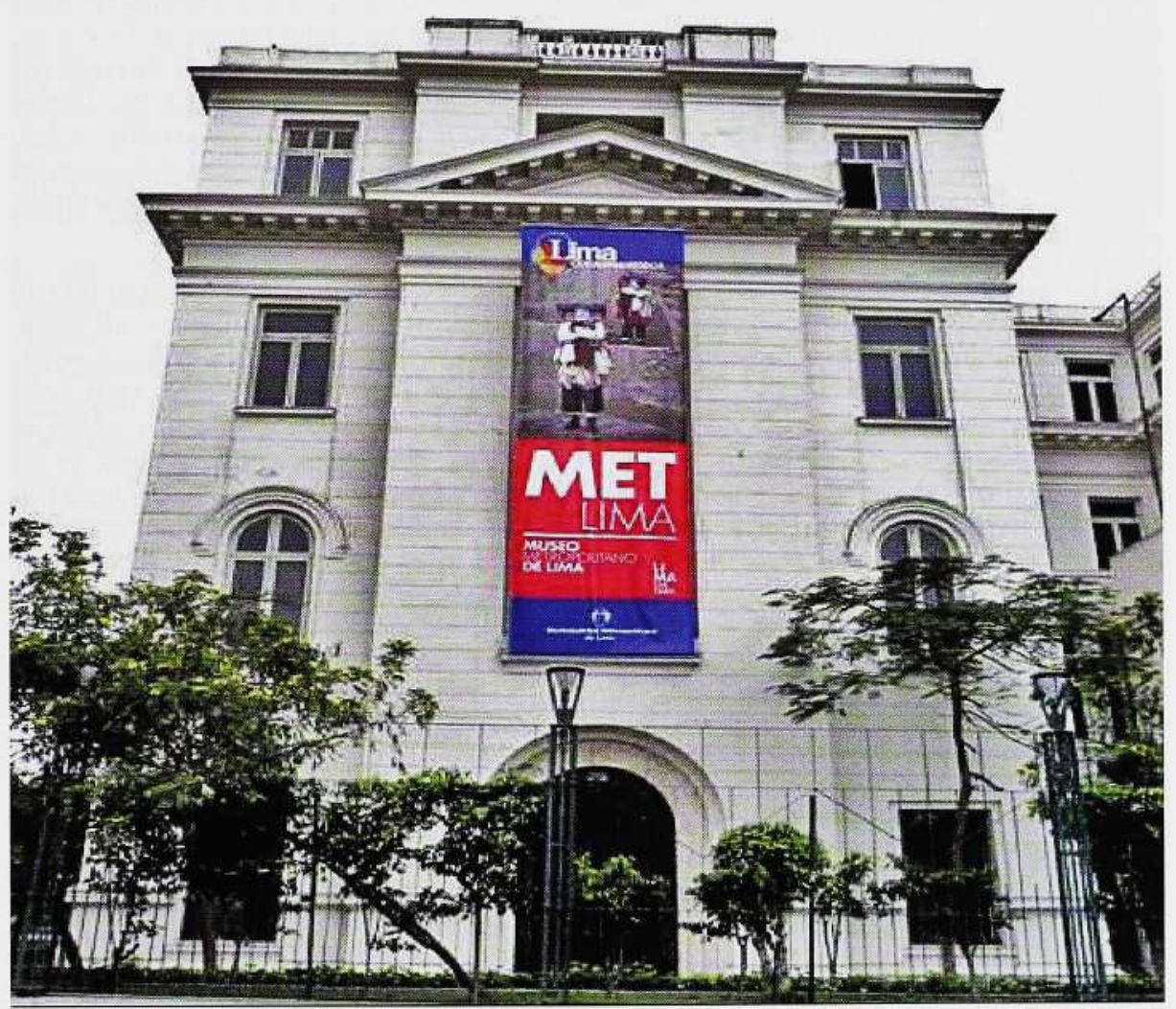

En diciembre de 2010 se inauguró el Museo Metropolitano de Lima y me alegré pensando que por fin tendríamos un museo sobre la historia y el desarrollo urbano de nuestra ciudad capital; pero mi entusiasmo decayó después de mi visita a las nuevas instalaciones del adaptado ex ministerio de Transporte y Comunicaciones de la avenida 28 de julio. Durante todo este tiempo he pensado a qué se debe mi descontento y he encontrado algunas razones que puedo anotar apoyándome en argumentos estrictamente profesionales para comprender qué se propusieron los responsables del proyecto.

Comencemos por la denominación: ¿el Metropolitano es en realidad un "museo"? Aunque el afán muselizador de hoy día ha copado los temas, pues hay museos de las cosas más 
increibles, la tradición museológica ha dejado bien en claro que un museo para ser tal debe poseer una colección y debe investigar sobre ella. El tema de la historia de Lima y su desarrollo urbano puede y debe ilustrarse con objetos culturales sobre los que armar una narración interesante y verdadera con solo recolectar lo más representativo de los museos y colecciones de la capital. Es decir, hay material abundante. Los objetos originales que representan la vida de la ciudad, desde un cántaro hasta una carroza virreinal, son documentos que acreditan la razón histórica, la credibilidad de lo narrado y la fe en lo acontecido. El término, pues, de "museo" le queda grande al Metropolitano de Lima. Para el tipo de institución que no posee colecciones la museología está usando la denominación "Centro de Interpretación", donde priman las imágenes fotográficas, las ilustraciones y los videos, etc.

Los responsables del proyecto se propusieron hacer un museo, pero por defecto les salió otra cosa: resultó una película en secuencia, una serial, a lo largo del recorrido. En efecto, el visitante tiene ante sus ojos recreaciones cinematográficas gracias al uso de proyectores que funcionaron las primeras semanas después de la inauguración, pero que luego fueron apagándose penosamente. Aquí es donde dos realidades chocan estrepitosamente: la tecnología de punta vs. la economía tercermundista. El resultado ha sido la clausura sucesiva de varias salas que ha empobrecido la visita; además reponer los focos de los proyectores está fuera de todo presupuesto de un museo autofinanciado.

Está bien usar videos que colaboren con la mejor comprensión del mensaje, pero no son los únicos medios a disposición de la museografía de hoy; están las maquetas, los maniquíes, los dioramas, pero sobre todo los objetos reales que hacen más variada la visita. Habría que agregar: con un ahorro considerable. Temas hay abundantes; por citar unos cuantos: de dónde viene el trazado en cuadrícula de la Lima que fundó Pizarro, cómo se surtía de agua la capital, disposición de la casa limeña, el origen de los nombres de las calles y las profesiones, cómo estaba compuesto el gobierno municipal, y así, pasando por las parroquias y las cofradias, los hospitales, los talleres artesanales y de pintores, etcétera, se puede tener una idea cabal de las actividades públicas de nuestra capital.

Pero sigamos. El público no puede caminar libremente por el circuito: existe el peligro de que se pierda en los vericuetos y la oscuridad de la parte precolombina; tiene que esperar para formar grupos y luego dejarse conducir por el guía de turno. Así pues, el complicado itinerario de la visita depende, en un $100 \%$, de la palabra del guía, de su capacidad y de su temperamento. Pero cuando el grupo llega a una sala decorada al estilo Luis XVI (¿?) se percata de que estamos en otra época, supuestamente en el virreinato, y se lo invita a ver una película. Existe en la sala gran expectativa porque además se ofrece anteojos para ver el video en tres dimensiones. Se presentan cuatro historias alternadas de la vida de los limeños y la secuencia del palacio del Virrey Conde de Superunda, es lamentable porque no dice nada sustancial para comprender la historia de la ciudad.

No voy a entrar en los particulares de la película, lo cierto es que mientras el público está entretenido con los efectos de la tridimensionalidad, comienza a simularse un terremoto en la sala para dar mayor fuerza a las imágenes que está viendo. Para quienes hemos vivido varios terremotos limeños no deja de impresionarnos, pero el público asistente lo recibe con beneplácito porque es parecido al "tren fantasma" de los Luna Park populares, es decir provoca un miedo agradable. La experiencia cultural se ha convertido en una secuencia morbosa: el museo ha vendido su primogenitura por una experiencia banal. Muchos visitantes están de acuerdo en que el "terremoto" constituye el "jale" del museo, pero a qué costo. Esperamos que las autoridades de la institución tengan un plan de evacuación eficiente para sacar al público de esa sala por los vericuetos oscuros el día que-Dios no lo quiera- haya un terremoto de verdad o un incendio.

La impresión que deja la visita, en general, es de una continua oscuridad y de recorridos 
tortuosos que sólo se iluminan al momento de presentar el show. Se comprende entonces que el proyecto haya sido encomendado a un hombre de cine, donde las imágenes virtuales necesitan de un espacio cerrado y oscuro por un lado, y por otro, bajar el nivel de los contenidos hacia lo anecdótico o la fábula, en detrimento de la historia, para entretener a los espectadores. No pongo en duda las dotes del cineasta, pero el proyecto necesita un replanteamiento con circuitos más cortos e iluminados, con objetos culturales originales que refuercen y no distorsionen la historia y con una dosis de tecnología manejable. Esto supone, por supuesto, dejar de lado la opción de "exposición cinematográfica por tramos", para volver a la tradicional muestra por secuencias con objetos reales, es decir un museo de verdad.

\section{Sobre el guión museográfico}

De un tiempo a esta parte se viene utilizando la denominación de "guión museológico" para referirse al ordenamiento de las necesidades tanto organizativas como espaciales relacionadas netamente con la museología y lo que se ha dado en llamar "plan museológico". Por ejemplo, la correlación entre espacios y funciones de un museo. No se dónde se ha originado, pero se usa sobre todo en las dependencias del Ministerio de Cultura por una inexplicable desinformación.

En cambio en el lenguaje tradicional de los museos se ha venido empleando "guion museográfico"(GM) al documento que ordena secuencialmente los temas en una exposición en vista a lograr un buen diseño. Su nombre proviene del argot cinematográfico donde marca las acciones y parlamentos del actor y las escenas que conforman una película. Adaptado a la museología, el guión estructura y sistematiza la información que se va a transmitir, define los temas y subtemas, la distribución de los objetos así como los textos que formarán parte de la exposición constituyendo secuencias.

El GM debe contener básicamente dos tipos de información, el texto que contextualiza los objetos que se incorporan en la muestra y las características puntuales de cada una de las piezas (función, tipología, materiales, cultura, colección, cultura, medidas, etcétera). Esta última información sirve para realizar la "cartela" o "pie de objeto". El GM por su origen, tiene siempre algo que decir, es la voz mediadora de los científicos que haciendo un esfuerzo de sintesis lo presentan a través de estrategias discursivas al alcance de todos.

NO EXISTE pues el "guión museológico" para designar la organización de los espacios o las funciones de un museo. Existe desde siempre, en el lenguaje arquitectónico, la palabra "programa" para designar los requerimientos espaciales y funcionales de un edificio que puede aplicarse a un estadio, un hospital o un museo. La programación no tiene por finalidad decir algo (un texto), sino cuantificar y ordenar las necesidades del futuro museo de acuerdo a sus propias necesidades. 